\title{
PROCESSING OF A METAL CONCENTRATE FROM GROUND WASTE PRINTED CIRCUIT BOARDS IN ACIDIC MEDIA USING HYDROGEN PEROXIDE AS OXIDANT
}

\author{
Calvin Sampaio Moreira da Silva, Guido Tande Crespo Zebaa, Christiano Mota Rodrigues da Rocha ${ }^{\text {a }}$, Pedro Rosário

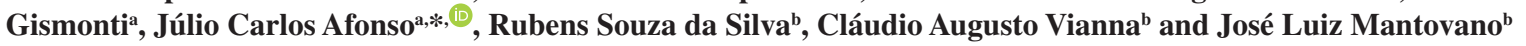 \\ aDepartamento de Química Analítica, Instituto de Química, Universidade Federal do Rio de Janeiro, 21941-909 Rio de Janeiro \\ - RJ, Brasil \\ bDepartamento de Química e Materiais Nucleares, Instituto de Engenharia Nuclear, 21941-972 Rio de Janeiro - RJ, Brasil
}

Recebido em 09/03/2020; aceito em 28/04/2020; publicado na web em 22/06/2020

\begin{abstract}
The recovery of precious and base metals of a metal concentrate from ground waste printed circuit boards (PCBs) is described in detail. Samples were treated with $\mathrm{NaOH}_{\text {aq. }}$ to remove the soldering mask. Experiments were performed in acidic medium (HF, $\mathrm{H}_{2} \mathrm{SO}_{4}, \mathrm{CH}_{3} \mathrm{COOH}$ or $\mathrm{H}_{3} \mathrm{PO}_{4}$ ) using $\mathrm{H}_{2} \mathrm{O}_{2}$ as oxidant. Base metals were leached in high yields $(>99 \mathrm{wt} . \%)$ at $\sim 40{ }^{\circ} \mathrm{C}$ after $\sim 1 \mathrm{~h}(\mathrm{HF})$, $\sim 2 \mathrm{~h}\left(\mathrm{H}_{2} \mathrm{SO}_{4}\right), \sim 4 \mathrm{~h}\left(\mathrm{H}_{3} \mathrm{PO}_{4}\right)$ and $\sim 5 \mathrm{~h}\left(\mathrm{CH}_{3} \mathrm{COOH}\right)$. Lead precipitated in the presence of $\mathrm{H}_{2} \mathrm{SO}_{4}$ and $\mathrm{HF}$. Precious metals were not oxidized. Ceramic/fiberglass components were dissolved in the presence of HF. Silver, palladium and gold were recovered from the insoluble solid, in this order, by a sequential oxidative treatment in aqueous medium. Recovery of leached elements was possible by a combination of solvent extraction and precipitation. The choice of the extractant and the precipitant were essential to recover them with high yields. The leachates from $\mathrm{H}_{3} \mathrm{PO}_{4}+\mathrm{H}_{2} \mathrm{O}_{2}$ experiments could not be processed above $\mathrm{pH}$ 2.5. Leaching of waste PCBs in the presence of a weak organic acid is possible but a multistage separation scheme for elements recovery is unavoidable as PCBs is a complex material in terms of composition.
\end{abstract}

Keywords: PCBs; precious metals; acidic leaching; metals recovery.

\section{INTRODUCTION}

Production of electrical and electronic equipment (EEE) is one of the fastest growing sectors in the world. Technology advances drive the production of new electronics while making them more accessible to the final customer. With new technological innovation, the replacement of equipment is persistently accelerating the generation of waste electrical and electronic equipment (WEEE or "e-waste") on a global scale. ${ }^{1,2}$ According to the Solving the E-Waste Problem Initiative, the volume of end-of-life electronics worldwide is expected to jump to 65.4 million tonnes annually by 2017 and 75 million tonnes by $2030 .{ }^{3}$ According to the European Union, the growth rate of WEEE in the past 6 years is 4 times of ordinary municipal waste. ${ }^{4}$ WEEE is considered the most rapidly growing pollution problem because they contain high amounts of hazardous compounds. ${ }^{5,6}$ The variety and content of toxic and valuable elements in WEEE are far more than other forms of municipal waste. ${ }^{7-9}$

Printed circuit boards (PCBs) are essential components of EEE. ${ }^{7,10,11}$ Manufacture of mobile phones and personal computers (PCs) consumes considerable fractions of gold, silver and palladium mined annually worldwide. ${ }^{7}$ The metals present in PCBs usually cross-link to ceramic materials or organic compounds which are usually toxic and may bioaccumulate, such as brominated flame retardants, polybrominated diphenyl ethers and polycyclic aromatic hydrocarbons. ${ }^{6,10,12-14}$ Direct discard of waste PCBs leads to environmental pollution ${ }^{7,8}$ and loss of valuable components. ${ }^{10}$

$\mathrm{PCBs}$ is the most economically attractive portion of $\mathrm{WEEE}^{5,7,10}$ because elements such as copper, aluminum, nickel, lead, tin, silver and gold are more highly concentrated in PCBs than in mineralrich ores. ${ }^{6,7}$ Recycling of PCBs has received wide concern as their amount has been increasing dramatically. ${ }^{4,9}$ This strategy requires the development of appropriate management approaches, ${ }^{8}$ but it has been

*e-mail: julio@iq.ufrj.br proved that it is worthwhile to recycle electronic scrap despite the content of precious metals steadily decreases. ${ }^{7}$ This viewpoint also includes special elements ( $\mathrm{Se}, \mathrm{Te}, \mathrm{Sb}, \mathrm{Bi}, \mathrm{In}$ ) with a strong further growth potential ${ }^{6}$ and the extraction of other metals of lesser value which may be potentially hazardous, as for example $\mathrm{Cd}$ and $\mathrm{Pb} .{ }^{15}$ At present only about $15 \%$ of the scrap PCBs are subjected to any kind of recycling. ${ }^{16}$

WEEE recycling is not simple and straightforward: up to 60 different elements are closely interlinked with complex assemblies and sub-assemblies. ${ }^{6,10,12}$ The existing studies have focused on two major aspects: (1) enrichment of metallic or nonmetallic components of waste PCBs; (2) recovery of valuable metals or fiberglass resin from concentrate. ${ }^{7}$ Currently, recycling of waste PCBs is mainly focused on metals; recycling of non-metallic material is rather less because of difficulty to dispose and low economic benefits. ${ }^{4}$ The mainstream methodology to recover metals from PCBs consists in size reduction (dismantling, crushing, shredding, comminution, grinding), followed by separation using physical properties such as magnetic and density, among others. ${ }^{2,11,17,18}$ This step is essential because PCBs have high hardness and tenacity. ${ }^{6}$ However, loss of material (up to 40 wt. \%) as dust may take place,,${ }^{17}$ thus requiring environmental control measures. In a further step, the metal fractions are processed via hydrometallurgical, pyrometallurgical, electrometallurgical, biohydrometallurgical processes and their combinations. ${ }^{7}$ A number of both environmentally friendly and economically novel processes have been proposed to improve the recycling efficiency of waste PCBs and obtain multiple products, ${ }^{6}$ such as cryogenic milling, ${ }^{12}$ corona electrostatic separation, ${ }^{6}$ vacuum metallurgical technology, mild extracting and electrochemical techniques. ${ }^{9}$ Although special advantages come from these technologies, most of them are still on lab-scale and defects accompany also. ${ }^{7,9}$

Hydrometallurgical processes are preferred for recovery of precious metals ( $\mathrm{Ag}, \mathrm{Au}, \mathrm{Pd}, \mathrm{Pt}$ ) from $\mathrm{PCBs}^{19}$ because of relatively low capital costs, low or no gas/dust formation, operational selectivity 
and suitability for small scale applications, low energy consumption, high recovery rate, no slag generation except few plastics and easy working condition. ${ }^{6,10,17}$ Leaching has a prominent role. The so called base metals ( $\mathrm{Zn}, \mathrm{Ni}, \mathrm{Fe}, \mathrm{Cr}$ etc.) are leached by diluted strong inorganic acids $\left(\mathrm{HNO}_{3}, \mathrm{H}_{2} \mathrm{SO}_{4}, \mathrm{HCl}\right)$ under moderate experimental conditions. ${ }^{911,14,15,20,21}$ Copper and precious metals are leachable in an oxidant medium. ${ }^{14,18}$ Hydrogen peroxide $\left(\mathrm{H}_{2} \mathrm{O}_{2}\right)$, a safe, powerful and versatile oxidant in acidic solution, ${ }^{22}$ is widely used as co-reactant. Other oxidants include $\mathrm{Cl}_{2}, \mathrm{O}_{2}, \mathrm{ClO}_{3}^{-}$ions and aqua regia. ${ }^{13,14,18} \mathrm{In}$ some researches a mineral acid is used in the first stage of leaching for base metals, followed by an oxidative leachant for precious metals leaching. ${ }^{14}$ These methods are usually time-consuming, require fine grinding for efficient leaching, present high reagent consumption, and generate secondary effluents. ${ }^{10,14,17}$ In recent years, hydrometallurgical technology has driven attention towards non-polluting, efficient and low cost processes for recycling of PCBs. Mild leaching agents and modified technologies (including bioleaching ${ }^{23,24}$ and chelating leaching ${ }^{14}$ ) have been put forward and have gained considerable progress.

A variety of methods, such as solvent extraction (SX), adsorption, cementation, precipitation, and electrolysis, have been used to obtain precious metal products from the leachates. ${ }^{14,18,23,24}$ As more elements are leached, the leachate becomes more complex to be processed. Selection and combination of separation and recovery methods are determined according to the leachant used, metals concentration in the leachates and target elements and impurities, ${ }^{14}$ but most of them are still on laboratory scale. Efficient, low cost and environmentally friendly refining technologies are requisite and urgent. ${ }^{6}$

This study aimed to recover precious and base metals from a metal concentrate from ground waste PCBs under mild experimental conditions on lab-scale in new acidic media: i) hydrofluoric acid (HF) and $\mathrm{H}_{2} \mathrm{O}_{2}$ mixtures, following the same procedure applied to non-ground PCBs of cell phones. ${ }^{25,26}$ This acid reacts with the PCB laminate (ceramic/fiberglass components), thus increasing exposition of metals to the leachant. ${ }^{25}$ Fluoride is a very hard base and forms very stable complexes with cations with noble gas-like configuration (hard acids) like $\mathrm{Al}^{3+}, \mathrm{Sn}^{4+}$ and $\mathrm{Fe}^{3+, 27,28}$ ii) syrupy phosphoric acid in the presence of $\mathrm{H}_{2} \mathrm{O}_{2}$. This acid is able to dissolve many geological samples, such as silicates. ${ }^{29,30}$ A stable and soluble silicon pyrophosphate $\left(\mathrm{SiP}_{2} \mathrm{O}_{7}\right)$ is the key to dissolve such samples; iii) acetic acid and $\mathrm{H}_{2} \mathrm{O}_{2}$ mixtures for selective leaching of copper and base metals without using a corrosive strong inorganic acid. Leaching with $\mathrm{H}_{2} \mathrm{SO}_{4}+\mathrm{H}_{2} \mathrm{O}_{2}$ mixtures were also performed for comparison purposes. The influence of the leachant on recovery of precious metals from the insoluble matter and the base metals from the leachate was determined.

\section{EXPERIMENTAL}

Di-2-ethylhexylphosphoric acid (D2EHPA, 98 wt.\% from British Drug Houses Ltd.), bis-2,4,4-trimethylpentyl/ phosphinic acid (Cyanex 272, 99 wt.\%, from Cytec) and LIX984 (a mixture of 5-nonylsalicylaldoxime and 2-hydroxy-5-nonyl-acetophenone oxime from Cognis) were used as extractants. Deodorized kerosene (Exxon) was used as diluent. Sodium hydroxide, sulfuric acid (98 wt.\%, $\sim 18 \mathrm{~mol} \mathrm{~L}^{-1}$ ), hydrofluoric acid (40 wt. $\%, \sim 20 \mathrm{~mol} \mathrm{~L}^{-1}$ ), hydrogen peroxide (30 wt. $\%, \sim 10 \mathrm{~mol} \mathrm{~L}^{-1}$ ), syrupy phosphoric acid (85 wt.\%, $\left.\sim 14.8 \mathrm{~mol} \mathrm{~L}^{-1}\right)$, glacial acetic acid $\left(\sim 17 \mathrm{~mol} \mathrm{~L}^{-1}\right)$, potassium iodide, potassium bromide and absolute ethanol were of analytical grade and were used as received without further purification. The solutions were prepared with distilled water. The acids were handled using appropriate personal protective equipment (chemical splash goggles together with a face shield, neoprene rubber gloves that cover the hands, wrists, and forearms and a laboratory coat).

\section{PCB samples}

A number of PCBs from obsolete computers (mother boards) were collected from an inventory of obsolete components at a dismantling WEEE unit. The PCBs were cut into pieces of approximately $2 \times 80 \mathrm{~mm}$ and ground in a knife mill to a size smaller than $1 \mathrm{~mm}$ to achieve satisfactory metal liberation. This powder was classified with sieves and the size fraction between $0.2-0.4 \mathrm{~mm}$ was used to obtain a metal concentrate through a pneumatic method. The coarser fraction was ground again. The concentration process is described elsewhere. ${ }^{31}$ The concentrate contains approximately $48 \mathrm{wt} . \%$ copper, $40 \mathrm{wt} . \%$ other metals and $12 \mathrm{wt} . \%$ non-metallic materials. ${ }^{32}$

\section{Processing of the metal concentrate}

\section{First step: removal of the soldering mask}

Taking into account that epoxy resins are frequently used as coatings, ${ }^{33-35}$ samples were immersed in $6 \mathrm{~mol} \mathrm{~L}^{-1} \mathrm{NaOH}\left(10 \mathrm{~mL} \mathrm{~g}^{-1}\right.$ PCB) in a Teflon beaker at $50^{\circ} \mathrm{C}$ for $1-4 \mathrm{~h}$ under stirring ( 100 rotations per minute). The solid was isolated by filtration through a plastic sieve $(0.1 \mathrm{~mm})$, washed with water $\left(6 \mathrm{~mL} \mathrm{~g}^{-1}\right)$, dried at $25^{\circ} \mathrm{C}$ and weighed. A very fine milky solid deposited at the bottom of the beaker. It was filtered, washed with water $\left(3 \mathrm{~mL} \mathrm{~g}^{-1}\right)$, dried at $25{ }^{\circ} \mathrm{C}$ and weighed. The dried solid was placed in a ceramic crucible and calcined in a furnace $\left(600{ }^{\circ} \mathrm{C}, 3 \mathrm{~h}\right)$. The roasted mass was cooled down in the furnace and weighed.

\section{Second step: chemical leaching}

All experiments were carried out in a fume hood in $250 \mathrm{~mL}$ closed Teflon vessels. The solid/liquid ratio was fixed at $100 \mathrm{~g} \mathrm{PCB} \mathrm{L}^{-1}$ leachant. This ratio is commonly used in preliminary studies involving leaching. ${ }^{6,18}$ The leachants were prepared mixing the concentrated acid and aqueous hydrogen peroxide in equal volumes. The final acid concentration range (7.4- $\left.10 \mathrm{~mol} \mathrm{~L}^{-1}\right)$ is frequently found in many studies involving PCBs and inorganic acids..$^{14,18,21,25}$ Initial temperature was $25^{\circ} \mathrm{C}$. Stirring was fixed at 200 rotations per minute. After adding the treated metal concentrate to the leachant, temperature increased by $5-10{ }^{\circ} \mathrm{C}$ (acetic and phosphoric acids) to $15^{\circ} \mathrm{C}$ (sulfuric and hydrofluoric acids) after $\sim 1 \mathrm{~h}$. Temperature was set at $40^{\circ} \mathrm{C}$ from $1 \mathrm{~h}$ until the end of the experiment. The equations describing the possible reactions between copper, zinc, nickel, lead, tin, aluminum, iron and silicon dioxide with $\mathrm{HF}$ and $\mathrm{H}_{2} \mathrm{O}_{2}$ are given elsewhere. ${ }^{25}$ The equations for the other acids (at $40{ }^{\circ} \mathrm{C}$ ) are the following: ${ }^{36}$

$$
\begin{array}{lc}
\mathrm{Cu}+\mathrm{H}_{2} \mathrm{O}_{2}+2 \mathrm{H}^{+} \rightarrow \mathrm{Cu}^{2+}+2 \mathrm{H}_{2} \mathrm{O} & \Delta \mathrm{G}^{0}=-71.3 \mathrm{~kJ} \\
\mathrm{Ni}+\mathrm{H}_{2} \mathrm{O}_{2}+2 \mathrm{H}^{+} \rightarrow \mathrm{Ni}^{2+}+2 \mathrm{H}_{2} \mathrm{O} & \Delta \mathrm{G}^{0}=-88.3 \mathrm{~kJ} \\
\mathrm{Zn}+\mathrm{H}_{2} \mathrm{O}_{2}+2 \mathrm{H}^{+} \rightarrow \mathrm{Zn}^{2+}+2 \mathrm{H}_{2} \mathrm{O} & \Delta \mathrm{G}^{0}=-147.1 \mathrm{~kJ} \\
\mathrm{~Pb}+\mathrm{H}_{2} \mathrm{O}_{2}+\mathrm{H}_{2} \mathrm{SO}_{4} \rightarrow \mathrm{PbSO}_{4(\mathrm{~s})}+2 \mathrm{H}_{2} \mathrm{O} & \Delta \mathrm{G}^{0}=-77.1 \mathrm{~kJ} \\
\mathrm{~Pb}+\mathrm{H}_{2} \mathrm{O}_{2}+2 \mathrm{CH}_{3} \mathrm{COOH} \rightarrow \mathrm{Pb}\left(\mathrm{CH}_{3} \mathrm{COO}\right)_{2}+2 \mathrm{H}_{2} \mathrm{O} \\
\multicolumn{3}{c}{\Delta \mathrm{G}^{0}=-82.3 \mathrm{~kJ}} \\
\mathrm{Sn}+2 \mathrm{H}_{2} \mathrm{O}_{2}+4 \mathrm{H}^{+} \rightarrow \mathrm{Sn}^{4+}+4 \mathrm{H}_{2} \mathrm{O} & \Delta \mathrm{G}^{0}=-78.9 \mathrm{~kJ} \\
2 \mathrm{Al}+3 \mathrm{H}_{2} \mathrm{O}_{2}+6 \mathrm{H}^{+} \rightarrow 2 \mathrm{Al}^{3+}+6 \mathrm{H}_{2} \mathrm{O} & \Delta \mathrm{G}^{0}=-189.6 \mathrm{~kJ} \\
2 \mathrm{Fe}+3 \mathrm{H}_{2} \mathrm{O}_{2}+6 \mathrm{H}^{+} \rightarrow 2 \mathrm{Fe}^{3+}+6 \mathrm{H}_{2} \mathrm{O} & \Delta \mathrm{G}^{0}=-122.0 \mathrm{~kJ} \\
\mathrm{SiO}_{2}+\mathrm{H}_{4} \mathrm{P}_{2} \mathrm{O}_{7} \rightarrow \mathrm{SiP}_{2} \mathrm{O}_{7}+2 \mathrm{H}_{2} \mathrm{O} & \Delta \mathrm{G}^{0}=-23.2 \mathrm{~kJ}
\end{array}
$$

All calculated values of $\Delta \mathrm{G}^{0}$ are negative. It follows that the reactions occur with high probability in the direction of product formation at $40{ }^{\circ} \mathrm{C}$. Some of the above reactions have already been observed in previous works in sulfuric, ${ }^{6,14,21}$ hydrofluoric ${ }^{25}$ and phosphoric ${ }^{29}$ media.

In all experiments an insoluble matter was found. It consisted of a coarse and a very fine solid. The leachate was passed through a plastic sieve $(0.1 \mathrm{~mm})$ in order to retain the coarse solid, which was washed 
with water $\left(6 \mathrm{~mL} \mathrm{~g}^{-1}\right.$ processed concentrate) and dried at $110{ }^{\circ} \mathrm{C}$ for $2 \mathrm{~h}$ and weighed. This solid was placed in a ceramic crucible and calcined in a furnace $\left(1000{ }^{\circ} \mathrm{C}, 3 \mathrm{~h}\right)$. The roasted mass was cooled down in the furnace and weighed. The washings and the filtrate were combined and filtered (under vacuum) through a quantitative filter paper. The fine solid was washed with water $\left(4 \mathrm{~mL} \mathrm{~g}^{-1}\right.$ processed concentrate), dried at $110{ }^{\circ} \mathrm{C}$ for $2 \mathrm{~h}$ and weighed.

All experiments were performed to verify the reproducibility of them. It was found that the error percentage was on the order of $\pm 5 \%$. The leachates were handled in a fume hood using appropriate personal protective equipment.

\section{Processing of the fine solid}

It is expected that the fine solid is composed by precious metals, lead salts $\left(\mathrm{PbF}_{2}, \mathrm{PbSO}_{4}\right)$ non-leached fiberglass components and the polymer substrate.

The first step was to leach lead from the fine solid. $\mathrm{PbF}_{2}$ was dissolved in water ${ }^{25,27,37}$ at $\sim 90-100{ }^{\circ} \mathrm{C}$ under stirring (200 rotations per minute) for $1 \mathrm{~h} .{ }^{26,37}$ The hot solution was filtered under vacuum as quickly as possible. The solid containing $\mathrm{PbSO}_{4}$ was first treated with $2 \mathrm{~mol} \mathrm{~L}^{-1} \mathrm{HNO}_{3}$ at $50{ }^{\circ} \mathrm{C}$ for $1 \mathrm{~h}$ to remove base metals such as $\mathrm{Al}, \mathrm{Fe}$ and $\mathrm{Sn}$. In a second step, $\mathrm{HCl} 6 \mathrm{~mol} \mathrm{~L}^{-1}$ selectively dissolved $\mathrm{PbSO}_{4}$ at $25{ }^{\circ} \mathrm{C}$ under stirring after $30 \mathrm{~min}:{ }^{28}$

$$
\begin{gathered}
\mathrm{PbSO}_{4}+4 \mathrm{HCl} \rightarrow\left[\mathrm{PbCl}_{4}\right]^{2-}+\mathrm{SO}_{4}{ }^{2-}+4 \mathrm{H}^{+} \\
\mathrm{K} \approx 2 \times 10^{8}
\end{gathered}
$$

The insoluble matter was separated by centrifugation. Eventually, lead can be precipitated as hydroxide: ${ }^{27}$

$$
\begin{aligned}
{\left[\mathrm{PbCl}_{4}\right]^{2-}+2 \mathrm{NaOH} } & \rightarrow \mathrm{Pb}(\mathrm{OH})_{2(\mathrm{~s})}+2 \mathrm{Na}^{+}+4 \mathrm{Cl}^{-} \\
\mathrm{K} & \approx 2.9 \times 10^{4}
\end{aligned}
$$

This precipitate was isolated by centrifugation. Both lead hydroxide and the insoluble matter were washed with water $\left(2 \mathrm{~mL} \mathrm{~g}^{-1}\right)$ and again centrifuged.

The insoluble matter after leaching $\mathrm{PbF}_{2}$ and the fine solid isolated after leaching with $\mathrm{H}_{3} \mathrm{PO}_{4}$ and $\mathrm{CH}_{3} \mathrm{COOH}$ were treated with $2 \mathrm{~mol}$ $\mathrm{L}^{-1} \mathrm{HNO}_{3}$ in order to oxidize traces of base metals ${ }^{27,28}$ and dissolve alkali-earth fluorides by conversion of fluoride ion to non-ionized HF. ${ }^{25}$ The precious metals are not affected. ${ }^{38}$

After removal of lead (when present) and base metals, all solids were subjected to a multistep oxidative leaching. In the first step, 8 mol L-1 $\mathrm{HNO}_{3}$ dissolved silver metal; ${ }^{25,27} 16 \mathrm{~mol} \mathrm{~L}^{-1} \mathrm{HNO}_{3}$ dissolved palladium metal; ${ }^{25}$ gold was brought into solution by digestion with aqua regia $\left(12 \mathrm{~mol} \mathrm{~L}-1 \mathrm{HCl}+16 \mathrm{~mol} \mathrm{~L}^{-1} \mathrm{HNO}_{3} 3: 1 \mathrm{vol} / \mathrm{vol}\right):^{27,28}$

$$
\begin{gathered}
\mathrm{Au}+4 \mathrm{HCl}+3 \mathrm{HNO}_{3} \rightarrow\left[\mathrm{AuCl}_{4}\right]^{-}+3 \mathrm{NO}_{2}+2 \mathrm{H}_{2} \mathrm{O}+\mathrm{H}_{3} \mathrm{O}^{+} \\
\Delta \mathrm{E}^{0}=+0.03 \mathrm{~V}
\end{gathered}
$$

It is expected that the polymer substrate and fiberglass components are the final insoluble matter. Experiments with $\mathrm{HNO}_{3}$ or aqua regia were run at $50{ }^{\circ} \mathrm{C}$ under stirring (200 rotations per minute) for $1 \mathrm{~h}$. The solid/liquid ratio was fixed at $5 \mathrm{~mL}$ oxidant $\mathrm{g}^{-1}$ solid. After each step, the remaining insoluble matter was isolated by centrifugation, washed with water $\left(3 \mathrm{~mL} \mathrm{~g}^{-1}\right)$, and again centrifuged. After gold leaching, the final solid was calcined at $1000{ }^{\circ} \mathrm{C}$ for $3 \mathrm{~h}$.

\section{Stability of the leachates}

The leachates were left to stand from 1 to $120 \mathrm{~h}$ at $25^{\circ} \mathrm{C}$ in order to assess their stability along time.
Leachate processing - SX of $\mathrm{Zn}(\mathrm{II}), \mathrm{Cu}(\mathrm{II}), \mathrm{Ni}(\mathrm{II}), \mathrm{Fe}(\mathrm{III})$, Sn(IV), Al(III) and stripping procedures

D2EHPA, a cation exchanger, is frequently used as extractant in both research and industrial applications. ${ }^{39}$ Many elements can be extracted and selectivity can be controlled by $\mathrm{pH}$ adjustment. ${ }^{40}$ However, as D2EHPA shows poor selectivity for $\mathrm{Zn}$ (II) over Fe(III) and Sn(IV), Cyanex 272 was employed as extractant for Fe(III) and $\mathrm{Sn}(\mathrm{IV})$ in acidic medium. ${ }^{41,42}$ LIX reagents (acid chelating extractants) are useful for copper extraction in acidic medium. ${ }^{43-47}$

Extraction experiments were performed in plastic separatory funnels at $25^{\circ} \mathrm{C}$. Extractant concentration varied from 1 to $20 \mathrm{vol} . \%$. The aqueous/organic (A/O) phase ratio was fixed at $1 \mathrm{vol} / \mathrm{vol} . \mathrm{pH}$ of the leachate was adjusted by adding the appropriate amount of $6 \mathrm{~mol} \mathrm{~L}^{-1} \mathrm{NaOH}$. The system was shaken for $10 \mathrm{~min}$. Phase separation was achieved in $\sim 10 \mathrm{~min}$. The experiments were carried out in triplicate and the experimental error including the analytical error was $4 \%$ at a confidence level of $95 \%$. The amount of element extracted was calculated by the difference between the concentration in the raffinate and the initial concentration in the original leachate.

Stripping experiments were carried out at $25^{\circ} \mathrm{C}$ using aqueous sulfuric acid in plastic separatory funnels. Its concentration varied from 0.01 to $5.0 \mathrm{~mol} \mathrm{~L}^{-1}$. The aqueous/loaded organic phase ratio (A/O) was fixed at $1 \mathrm{vol} / \mathrm{vol}$. The system was shaken for $10 \mathrm{~min}$. Phase separation was achieved in $\sim 6 \mathrm{~min}$. The experiments were carried out in triplicate and the experimental error including the analytical error was $3 \%$ at a confidence level of $95 \%$.

The separation scheme for leachates from $\mathrm{HF}+\mathrm{H}_{2} \mathrm{O}_{2}$ experiments is presented elsewhere. ${ }^{26} \mathrm{In}$ short, it involves $\mathrm{SX}$ of $\mathrm{Zn}$ (II), followed by $\mathrm{SX}$ of $\mathrm{Cu}(\mathrm{II})$, precipitation of $\mathrm{Na}_{3} \mathrm{XF}_{6}(\mathrm{X}=\mathrm{Al}, \mathrm{Fe}), \mathrm{SX}$ of $\mathrm{Ni}(\mathrm{II})$, crystallization of $\mathrm{NaF}+\mathrm{Na}_{2} \mathrm{SnF}_{6}+\mathrm{Na}_{2} \mathrm{SiF}_{6}$ and leaching of the tin salt by absolute ethanol. D2EHPA was the only extractant employed in the three SX steps.

\section{Leachate processing - precipitation of soluble lead(II)}

The leachates from $\mathrm{CH}_{3} \mathrm{COOH}+\mathrm{H}_{2} \mathrm{O}_{2}$ and $\mathrm{H}_{3} \mathrm{PO}_{4}+\mathrm{H}_{2} \mathrm{O}_{2}$ experiments were stirred (200 rotations per minute) at $25^{\circ} \mathrm{C} .1 \mathrm{~mol} \mathrm{~L}^{-1}$ $\mathrm{Na}_{2} \mathrm{SO}_{4}$ was added dropwise until precipitation of a white solid $\left(\mathrm{PbSO}_{4}\right)$ ceases. This solid was filtered through a quantitative paper, washed with $0.01 \mathrm{~mol} \mathrm{~L}^{-1} \mathrm{H}_{2} \mathrm{SO}_{4}$ followed by water and dried at $25^{\circ} \mathrm{C}$. As $\mathrm{SX}$ of $\mathrm{Pb}(\mathrm{II})$ is hindered by the interference of other metal ions that are preferentially extracted over it by the extractants employed in this work, ${ }^{39,42,44,46}$ precipitation of lead sulfate was chosen as it is specific for this metal ion among those leached. ${ }^{27,28}$

\section{Analytical methods}

Metal ion concentrations in the solutions were determined by atomic absorption spectrometry (Perkin Elmer AAS 3300) under the following operating conditions: air fow rate, $8 \mathrm{~L} \mathrm{~min}^{-1}$; acetylene flow rate, $2 \mathrm{~L} \mathrm{~min}^{-1}$; sample flow rate, $6 \mathrm{~mL} \mathrm{~min}^{-1}$; measurement time, $4 \mathrm{~s}$. The following wavelengths were employed: zinc, $213.9 \mathrm{~nm}$; iron, $248.3 \mathrm{~nm}$; lead, $283.3 \mathrm{~nm}$; nickel, $232.2 \mathrm{~nm}$; tin, $286.3 \mathrm{~nm}$; aluminum, $396.2 \mathrm{~nm}$; copper, $224.4 \mathrm{~nm}$; silicon, $251.6 \mathrm{~nm}$; silver, $328.1 \mathrm{~nm}$; gold, $242.8 \mathrm{~nm}$; palladium, $244.8 \mathrm{~nm}$. The detection and quantification limits for the different metals were determined experimentally and were found to be, respectively: 10 and $50 \mu \mathrm{g} \mathrm{L}^{-1}(\mathrm{Fe}) ; 5$ and $20 \mu \mathrm{g} \mathrm{L}^{-1}$ (Ag, $\mathrm{Zn}, \mathrm{Cu}$ and $\mathrm{Ni}$ ); 20 and $50 \mu \mathrm{g} \mathrm{L} \mathrm{L}^{-1}(\mathrm{Au}, \mathrm{Pd}) ; 15$ and $50 \mu \mathrm{g} \mathrm{L}^{-1}$ $(\mathrm{Pb}) ; 100$ and $400 \mu \mathrm{g} \mathrm{L}^{-1}$ (Al, Sn, Si). $\mathrm{pH}$ measurements of aqueous solutions were conducted by using a combination of a glass electrode and $\mathrm{a} \mathrm{Ag} / \mathrm{AgCl}$ reference electrode (Orion 2AI3-JG). Peroxide groups were investigated in the leachates according to the following reaction: 


$$
\begin{gathered}
\mathrm{H}_{2} \mathrm{O}_{2}+2 \mathrm{Br}+2 \mathrm{H}_{3} \mathrm{O}^{+} \rightarrow \mathrm{Br}_{2}+4 \mathrm{H}_{2} \mathrm{O} \\
\Delta \mathrm{E}^{0}=+0.70 \mathrm{~V}
\end{gathered}
$$

The presence of $\mathrm{Br}_{2}$ (dibromine) is a positive test for $\mathrm{O}_{2}{ }^{2-}$ groups. ${ }^{27,28}$

The solids obtained during processing of the metal concentrate were weighed in an analytical balance (Scientech SA 120) and analyzed by energy dispersive $\mathrm{X}$-ray fluorescence (XRF) in a Shimadzu EDX 800 HS with a rhodium target X-ray tube and a $\mathrm{Si}(\mathrm{Li})$ detector. The voltage of the $\mathrm{X}$-ray tube was $50 \mathrm{kV}$ and the current was $1 \mathrm{~mA}$. Samples were irradiated for $100 \mathrm{~s}$. The spectra were sequentially acquired from 0 to $40 \mathrm{keV}$ with energy steps of $0.5 \mathrm{keV}$. The quantification of the elements was carried out using the method of fundamental parameters (FP) with the software DXP700E Version 1.00 Rel. 014..$^{48,49}$ The detection limit was of the order of $1 \mathrm{mg} \mathrm{kg}^{-1}$. Samples were pressed into pellets with boric acid $\left(\mathrm{H}_{3} \mathrm{BO}_{3}\right)$ (1:4 mass ratio). Crystalline phases in the solid samples were identified by X-ray diffraction (XRD, Shimadzu XRD 6000) by continuous scanning method at $20 \mathrm{~mA}$ and $40 \mathrm{kV}$, using $\mathrm{Cu} \mathrm{K \alpha}$ $(\lambda=0.15418)$ as the radiation source. The diffraction angle $(2 \theta)$ was recorded from $10^{\circ}$ to $70^{\circ}$ at a scanning rate of $3^{\circ} \mathrm{min}^{-1}$.

\section{RESULTS AND DISCUSSION}

\section{Treatment of the metal concentrate with $6 \mathrm{~mol} \mathrm{~L}^{-1} \mathrm{NaOH}$}

After $1 \mathrm{~h}$ its mass loss was constant $(\sim 1.5 \mathrm{wt} \%$, Figure 1$)$. This loss is lower than the result reported for non-ground $\mathrm{PCBs}^{25}$ ( 2.5 wt.\%) since a metal concentrate was treated instead of a whole ground PCB. The inorganic elements present in the milky solid came mainly from the laminate: ${ }^{7,50,51} \mathrm{Si}(56.0 \mathrm{wt} . \%)$; $\mathrm{Ca}(14.1 \mathrm{wt} . \%)$; Ba (10.0 wt.\%); Fe (1.6 wt.\%); Mg (1.6 wt.\%); Al (0.2 wt.\%); Sn, Pb, $\mathrm{Zn}, \mathrm{Ni}, \mathrm{Sr}(<0.1 \mathrm{wt} . \%)$. Of particular interest is the presence of bromine (16.4 wt.\%) as it comes from the flame retardants added to the PCBs. ${ }^{51,52}$ After burning the milky solid, the ash corresponds to only $\sim 2$ wt. $\%$ of the original mass ( $\sim 0.03$ wt. $\%$ of the metal concentrate). Except for bromine, all elements cited above were found in this residue. The milky solid is essentially organic matter. Apart from sodium ions, XRF data did not detect any other metal present in the alkaline solution.

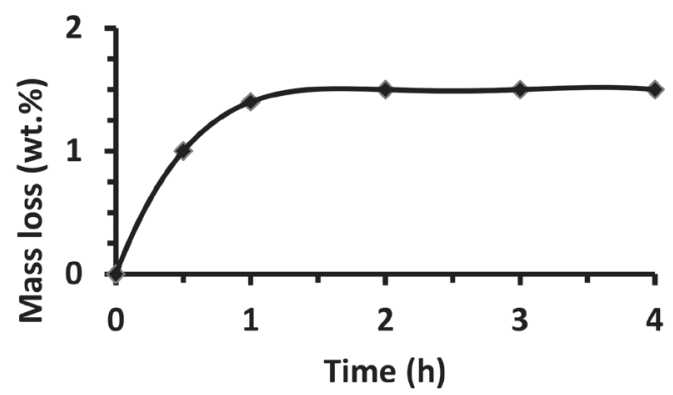

Figure 1. Mass loss of the metal concentrate after treatment with $6 \mathrm{~mol} \mathrm{~L}^{-1}$ $\mathrm{NaOH}$ at $50^{\circ} \mathrm{C}$

\section{Leaching of metal concentrate}

\section{Effect of pretreatment with $6 \mathrm{~mol} \mathrm{~L}^{-1} \mathrm{NaOH}$}

From data on Table 1, copper was more leached from samples previously treated with $\mathrm{NaOH}$ for a given time. Grinding of a PCB helps to achieve a satisfactory metal liberation under leaching (it increases the surface area ${ }^{6,32}$ but does not remove the soldering mask. Its removal appears to speed leaching as it increases metals exposure to the leachant. ${ }^{25}$

\section{Effect of time}

Copper was chosen to monitor the leaching processes as it is by far the most abundant metal in the samples under study. ${ }^{7,11,32} \mathrm{H}_{2} \mathrm{O}_{2}$ is essential to perform leaching as the acids alone are practically not reactive. It plays a double role during leaching: it oxidizes $\mathrm{Cu}, \mathrm{Pb}$, Sn etc. at the same time it is partially decomposed, thus heating the reaction mixture. ${ }^{25,26}$

Under the best experimental conditions, copper was highly leached (>99.5 wt.\%) by all leachants, but time required for such depended on the acid (Figure 2). HF leached it in a relatively short time $(\sim 1 \mathrm{~h})$ under very mild experimental conditions with respect to temperature $\left(T_{\max ,} \sim 40^{\circ} \mathrm{C}\right)$. This is the same result found when non-ground PCBs were leached. ${ }^{25}$ Time increased to $\sim 2 \mathrm{~h}$ in the presence of $\mathrm{H}_{2} \mathrm{SO}_{4}$. High copper leaching yields normally require longer times $(>2 \mathrm{~h})$ and higher temperatures $\left(>60^{\circ} \mathrm{C}\right)$ using ground $\mathrm{PCBs}$ in sulfuric, nitric or hydrochloric acid medium. ${ }^{7,9,11,20,53-56}$ The difference between our study and those of the literature is the removal of the soldering mask prior to leaching. Longer times were required in the presence of phosphoric $(\sim 4 \mathrm{~h})$ and acetic $(\sim 5 \mathrm{~h})$ acids. These acids are weaker than sulfuric acid and also presented the weakest thermal effects during leaching.

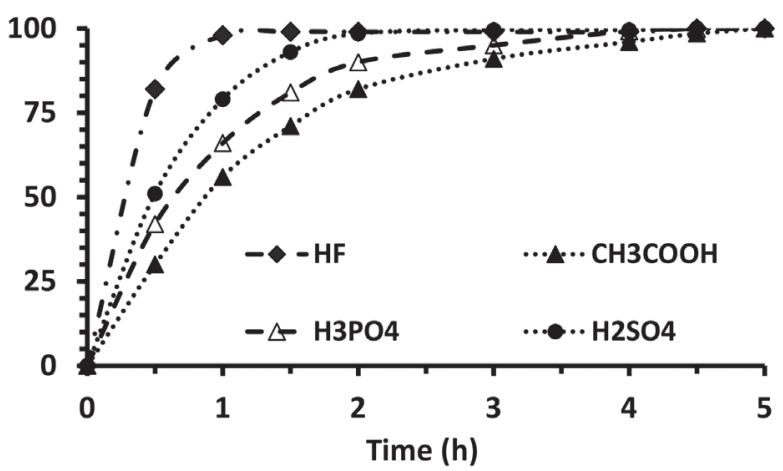

Figure 2. Effect of time on leaching. $\left[\mathrm{H}_{2} \mathrm{O}_{2}\right]=5 \mathrm{~mol} \mathrm{L^{-1 }}$. $[\mathrm{HF}]=10 \mathrm{~mol} \mathrm{~L}{ }^{-1}$; $\left[\mathrm{H}_{2} \mathrm{SO}_{4}\right]=9 \mathrm{~mol} \mathrm{~L}{ }^{-1} ;\left[\mathrm{H}_{3} \mathrm{PO}_{4}\right]=7.4 \mathrm{~mol} \mathrm{~L}^{-1} ;\left[\mathrm{CH}_{3} \mathrm{COOH}\right]=8.5 \mathrm{~mol} \mathrm{~L}^{-1}$

\section{Analysis of the coarse solid}

Under the best experimental conditions, the mass of the coarse solid is $\sim 7.5 \mathrm{wt}$. \% of the original one, whatever the leachant. Its aspect is quite different from the original sample (Figure 3). The metallic luster was lost and its specific mass is lower. After calcination, the

\begin{tabular}{|c|c|c|c|}
\hline \multirow{2}{*}{ Time (h) } & \multirow{2}{*}{ Leachant } & \multicolumn{2}{|c|}{ Leached copper (wt.\%) } \\
\hline & & Treated metal concentrate & Non-treated metal concentrate \\
\hline 1 & $10 \mathrm{~mol} \mathrm{~L}^{-1} \mathrm{HF}+5 \mathrm{~mol} \mathrm{~L}^{-1} \mathrm{H}_{2} \mathrm{O}_{2}$ & 99.7 & 94.0 \\
\hline 2 & $9 \mathrm{~mol} \mathrm{~L}^{-1} \mathrm{H}_{2} \mathrm{SO}_{4}+5 \mathrm{~mol} \mathrm{~L}^{-1} \mathrm{H}_{2} \mathrm{O}_{2}$ & 99.7 & 92.0 \\
\hline 4 & $7.4 \mathrm{~mol} \mathrm{~L}^{-1} \mathrm{H}_{3} \mathrm{PO}_{4}+5 \mathrm{~mol} \mathrm{~L}^{-1} \mathrm{H}_{2} \mathrm{O}_{2}$ & 99.5 & 89.0 \\
\hline 5 & $8.5 \mathrm{~mol} \mathrm{~L}^{-1} \mathrm{CH}_{3} \mathrm{COOH}+5 \mathrm{~mol} \mathrm{~L}^{-1} \mathrm{H}_{2} \mathrm{O}_{2}$ & 99.5 & 85.5 \\
\hline
\end{tabular}

Table 1. Leached copper from treated and non-treated metal concentrate samples 


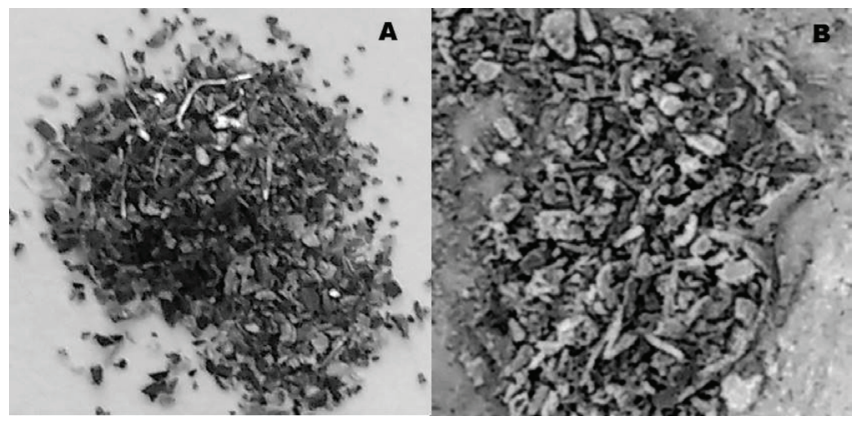

Figure 3. Typical aspect of the original metal concentrate (A) and the coarse solid (B) after leaching

ash corresponds only to $\sim 0.05 \mathrm{wt} . \%$ of the initial mass. Taking into account that $\sim 1.5 \mathrm{wt} . \%$ of the metal concentrate was dissolved by $\mathrm{NaOH}_{\text {aq. }}$, the above result suggests that the coarse solid is basically the polymer fraction of the sample under study. ${ }^{32}$

\section{Analysis of the fine solid}

The fine solid (Table 2) corresponds to 4.0-9.0 wt.\% of the metal concentrate. Its mass reflects the solubility of the elements in the leachants. Lead, precious and alkali-earth metals (> $80 \mathrm{wt} \%)$ are the main elements present after leaching with $\mathrm{HF}+\mathrm{H}_{2} \mathrm{O}_{2}$. Alkaliearth metals precipitated as fluorides $\left(\mathrm{XF}_{2}, \mathrm{X}=\mathrm{Mg}^{2+}, \mathrm{Ca}^{2+}, \mathrm{Sr}^{2+}\right.$, $\left.\mathrm{Ba}^{2+}\right)$. They are insoluble in water and $\mathrm{HF}_{\text {aq. }} \cdot{ }^{57}$ This leachant oxidized lead. ${ }^{25}$ It precipitated as $\mathrm{PbF}_{2}$ due to the high anion concentration in the leachates (common ion effect). ${ }^{27}$ Tin, silicon, aluminum and iron were highly leached $(>95 \mathrm{wt} . \%)$ as very stable $\left[\mathrm{SnF}_{6}\right]^{2-},\left[\mathrm{FeF}_{6}\right]^{3-}$, $\left[\mathrm{AlF}_{6}\right]^{3-}$ and $\left[\mathrm{SiF}_{6}\right]^{2-}$ ions were formed $\left(\mathrm{K}_{\text {form }}>10^{25}\right) .{ }^{28}$ The fine solids recovered after leaching with $\mathrm{H}_{3} \mathrm{PO}_{4}+\mathrm{H}_{2} \mathrm{O}_{2}$ or $\mathrm{CH}_{3} \mathrm{COOH}+\mathrm{H}_{2} \mathrm{O}_{2}$ mixtures are close one to each other. Lead is present in tiny amounts whereas silicon is the most abundant element (together with alkaliearth metals) as it was not leached by $\mathrm{CH}_{3} \mathrm{COOH}+\mathrm{H}_{2} \mathrm{O}_{2}$ or was only slightly leached by $\mathrm{H}_{3} \mathrm{PO}_{4}+\mathrm{H}_{2} \mathrm{O}_{2}$. This latter was not able to react with silicates as the experimental conditions are much milder than those described in the literature. ${ }^{29,30} \mathrm{H}_{2} \mathrm{SO}_{4}+\mathrm{H}_{2} \mathrm{O}_{2}$ produced the highest amount of fine solid. Silicon was not leached; lead was oxidized but precipitated as $\mathrm{PbSO}_{4}$.

\section{Lecahates composition}

As expected from data on Table 1, metal ion concentrations in the leachates did not change significantly after $1 \mathrm{~h}(\mathrm{HF})$ to $5 \mathrm{~h}$ $\left(\mathrm{CH}_{3} \mathrm{COOH}\right)$. According to data on Table 3, copper is largely the main element present, followed by iron, aluminum, nickel, zinc and tin. These are the main elements present in PCBs of PCs. ${ }^{7,20}$ The leachates are blue due to copper bearing ions. When lead and silicon are leached, their amount in the insoluble matter is very low (Table 2). $\mathrm{pH}$ of all leachates was in the range 1.0-1.2 after leaching for $1 \mathrm{~h}$ (or more).

\section{Elements distribution}

According to data of Tables 2 and 3, the elements can be divided into three groups: i) those which ever remained in the insoluble matter ( $\mathrm{Au}, \mathrm{Pd}, \mathrm{Ag}, \mathrm{Mg}, \mathrm{Ca}, \mathrm{Sr}, \mathrm{Ba})$; ii) those which were highly $(\mathrm{Cu}, \mathrm{Sn}$, Al, Fe: $>90$ wt.\%) or fully ( $\mathrm{Zn}, \mathrm{Ni}$ ) leached due to oxidation or complexation reactions; iii) those whose behavior depended on the leachant $(\mathrm{Pb}, \mathrm{Si})$. Lead was oxidized by all leachants but precipitated in the presence of fluoride $\left(\mathrm{PbF}_{2}\right)$ or sulfate $\left(\mathrm{PbSO}_{4}\right)$ ions. Silicon was leached in the presence of $\mathrm{HF}$ or $\mathrm{H}_{3} \mathrm{PO}_{4}$. The precious metals were not oxidized ${ }^{48}$ and were concentrated into a very small and less complex mass fraction (4.0-9.0 wt.\%) of the original metal concentrate (mass concentration factor of 11-25). This makes their separation by conventional methods easier. ${ }^{58}$

\section{Stability of the leachates}

Release of oxygen $\left(\mathrm{O}_{2}\right)$ was observed during about $8 \mathrm{~h}$ after finishing leaching. Also, the test for peroxide groups in the leachates was negative after $8 \mathrm{~h}$ whatever the leachant. No turbidity or precipitation took place even after 5 days when the leachants were left to stand at $25^{\circ} \mathrm{C}$, with the exception of those from the experiments in the presence of $\mathrm{H}_{3} \mathrm{PO}_{4}$. After $1 \mathrm{~h}$ the leachate became turbid, and a white solid began to deposit at the bottom of the flask one hour later. Deposition lasted three days. After filtration, the white solid was analyzed by XRF. Fe, $\mathrm{Al}, \mathrm{Pb}$ and $\mathrm{Sn}$ are the main elements present, which were almost fully precipitated (>95 wt.\%). Some Ni (0.1 wt.\%) and $\mathrm{Cu}(0.1 \mathrm{wt} . \%)$ were also found. The white solid is amorphous

Table 2. Mass percentage of elements in the fine solid*

\begin{tabular}{|c|c|c|c|c|c|c|c|c|c|c|c|c|c|}
\hline \multirow{2}{*}{ Time (h) } & \multicolumn{13}{|c|}{ Amount (wt.\%) } \\
\hline & $\mathrm{Cu}$ & $\mathrm{Ag}$ & $\mathrm{Au}$ & $\mathrm{Pd}$ & $\mathrm{Al}$ & $\mathrm{Fe}$ & $\mathrm{Pb}$ & $\mathrm{Sn}$ & $\mathrm{Si}$ & $\mathrm{Mg}$ & $\mathrm{Ca}$ & $\mathrm{Sr}$ & $\mathrm{Ba}$ \\
\hline $1(\mathrm{HF})$ & 2.9 & $1.2 \times 10^{1}$ & 7.8 & 1.2 & 3.7 & 4.0 & $5.4 \times 10^{1}$ & 4.0 & $1.0 \times 10^{-1}$ & 2.0 & 4.1 & $7.0 \times 10^{-1}$ & 3.4 \\
\hline $3\left(\mathrm{H}_{2} \mathrm{SO}_{4}\right)$ & 2.1 & $1.1 \times 10^{1}$ & 7.1 & 1.0 & 3.2 & 3.9 & $4.5 \times 10^{1}$ & 4.5 & $1.3 \times 10^{1}$ & 1.9 & 3.5 & $5.0 \times 10^{-1}$ & 2.9 \\
\hline $4\left(\mathrm{H}_{3} \mathrm{PO}_{4}\right)$ & 2.2 & $2.5 \times 10^{1}$ & $1.6 \times 10^{1}$ & 2.3 & 4.3 & 1.2 & $8.0 \times 10^{-1}$ & 3.7 & $2.5 \times 10^{1}$ & 4.0 & 8.3 & 1.1 & 6.4 \\
\hline $5\left(\mathrm{CH}_{3} \mathrm{COOH}\right)$ & 2.7 & $2.5 \times 10^{1}$ & $1.5 \times 10^{1}$ & 2.3 & 2.4 & 2.5 & $5.0 \times 10^{-1}$ & 2.5 & $2.8 \times 10^{1}$ & 4.2 & 8.2 & 1.1 & 6.2 \\
\hline
\end{tabular}

*metal concentrate pretreated with $6 \mathrm{~mol} \mathrm{~L} \mathrm{~L}^{-1} \mathrm{NaOH}$ for $1 \mathrm{~h}$.

Table 3. Average metal ion concentrations in the leachates

\begin{tabular}{|c|c|c|c|c|c|c|c|c|c|}
\hline \multirow{2}{*}{ Time (h) } & \multirow{2}{*}{ Leachant } & \multicolumn{8}{|c|}{ Concentration $\left(\mathrm{g} \mathrm{L}^{-1}\right)$} \\
\hline & & $\mathrm{Cu}$ & $\mathrm{Ni}$ & $\mathrm{Zn}$ & $\mathrm{Al}$ & $\mathrm{Fe}$ & $\mathrm{Pb}$ & $\mathrm{Sn}$ & $\mathrm{Si}$ \\
\hline 1 & $\mathrm{HF}+\mathrm{H}_{2} \mathrm{O}_{2}$ & $2.4 \times 10^{1}$ & 2.3 & 2.0 & 4.5 & 5.0 & $*$ & 1.7 & $6.8 \times 10^{-1}$ \\
\hline 2 & $\mathrm{H}_{2} \mathrm{SO}_{4}+\mathrm{H}_{2} \mathrm{O}_{2}$ & $2.4 \times 10^{1}$ & 2.3 & 2.0 & 4.5 & 5.4 & $*$ & 1.6 & $*$ \\
\hline 4 & $\mathrm{H}_{3} \mathrm{PO}_{4}+\mathrm{H}_{2} \mathrm{O}_{2}$ & $2.4 \times 10^{1}$ & 2.2 & 1.9 & 4.6 & 5.6 & 1.8 & 1.7 & $5.0 \times 10^{-2}$ \\
\hline 5 & $\mathrm{CH}_{3} \mathrm{COOH}+\mathrm{H}_{2} \mathrm{O}_{2}$ & $2.3 \times 10^{1}$ & 2.3 & 2.0 & 4.6 & 5.6 & 1.9 & 1.8 & $*$ \\
\hline
\end{tabular}

*below the limit of detection. 
according to XRD data, but it is likely that it is composed of normal orthophosphates $\left(\mathrm{FePO}_{4}, \mathrm{AlPO}_{4}, \mathrm{~Pb}_{3}\left(\mathrm{PO}_{4}\right)_{2}\right.$ and $\left.\mathrm{Sn}_{3}\left(\mathrm{PO}_{4}\right)_{4}\right)$.

\section{Processing of the fine solid}

\section{Recovery of lead (leachants: $\mathrm{HF}+\mathrm{H}_{2} \mathrm{O}_{2}$ and $\mathrm{H}_{2} \mathrm{SO}_{4}+\mathrm{H}_{2} \mathrm{O}_{2}$ )}

As expected, selective leaching of $\mathrm{PbF}_{2}$ with water proved to be very effective. ${ }^{25}$ The white solid contains $99.6 \mathrm{wt} . \%$ of lead present in the metal concentrate. Calcium (0.2 wt.\%) and barium (0.1 wt.\%) are the only foreign elements found according to XRF data. Its diffractogram corresponds to $\alpha-\mathrm{PbF}_{2} \cdot{ }^{25,59}$

Recovery of lead as $\mathrm{Pb}(\mathrm{OH})_{2}$ was also effective. More than 99.5 wt.\% of the element present in the metal concentrate. XRF data indicate the presence of tiny amounts of calcium ( $0.1 \mathrm{wt} . \%)$, tin $(0.2$ wt. $\%)$ and aluminum $(0.1 \mathrm{wt} . \%)$. Its diffractogram corresponds to an amorphous solid.

\section{Recovery of precious metals}

After leaching lead and base metals $(\mathrm{Cu}, \mathrm{Al}, \mathrm{Fe}, \mathrm{Sn})$, the composition of the fine solid (Table 4B-D) is comparable except when the leachant was $\mathrm{HF}+\mathrm{H}_{2} \mathrm{O}_{2}$ (Table 4A). It was the only one that dissolved silicon-bearing compounds. Alkali-earth fluorides are leachable by dilute $\mathrm{HNO}_{3}$. As a result, precious metals are dominant in the solid after treatment with $2 \mathrm{~mol} \mathrm{~L}^{-1} \mathrm{HNO}_{3}$ (Table 4A). On the other hand, alkali-earth silicates are not leachable by $2 \mathrm{~mol} \mathrm{~L}^{-1} \mathrm{HNO}_{3}$ (Table 4B-D). For this reason precious metals correspond to less than $50 \mathrm{wt} . \%$ of the fine solid in these cases.

Despite the presence of silicon and alkali-earth elements, the sequential treatment of the fine solid with nitric acid proved to be successful (Table 4) to recover silver (>99.5 wt.\%) and palladium (> 99.5 wt.\%) separately. ${ }^{25,60,61}$ The only difference was the time required to full oxidation of silver or palladium: $\sim 1 \mathrm{~h}$ in the presence of silicon and alkali-earth elements, and $~ 40 \mathrm{~min}$ in their absence. However, it was not possible to recover gold as the only final insoluble solid in any case. After digestion of the yellowish or light-brown solid with aqua regia, the solution was bright yellow characteristic of $\left[\mathrm{AuCl}_{4}\right]^{-}$ ions. Calcination of the residual final solid at $1000{ }^{\circ} \mathrm{C}$ for $3 \mathrm{~h}$ did not produce any visible ash when the leachant was $\mathrm{HF}+\mathrm{H}_{2} \mathrm{O}_{2}$. Therefore, it is composed of fine particles from the polymer substrate of the metal concentrate. ${ }^{32}$ These particles are absent when PCBs are not ground. ${ }^{25}$ Concerning the other leachants, a brown/brownish ash was isolated. According to data in Table 4, this ash contains silicon and alkali-earth metals.

\section{Processing of the leachates}

\section{SX of metal ions}

Data for the experiments involving acetic and sulfuric acids are shown in Figure 4. Fe(III) and Sn(IV) were extracted together (> 99.8 wt.\%) at the $\mathrm{pH}$ of the leachate $(\sim 1) . \mathrm{Zn}(\mathrm{II})$ was not coextracted, thus confirming the performance of Cyanex 272 as a selective extractant for $\mathrm{Fe}(\mathrm{III})$ and $\mathrm{Sn}(\mathrm{IV})$ over $\mathrm{Zn}(\mathrm{II}){ }^{41,42} \mathrm{~A}$ concentration of $10 \mathrm{vol} \%$ in kerosene was enough to extract then in a single stage.

D2EHPA proved to be a good extractant for $\mathrm{Zn}$ (II) in acidic medium. It was extracted from $\mathrm{pH} 0.5$ and was quantitatively removed from the aqueous phase at $\mathrm{pH} 1.8$. This means that only a small amount of $6 \mathrm{~mol} \mathrm{~L}^{-1} \mathrm{NaOH}$ is required to adjust the $\mathrm{pH}$ of the leachate before performing $\mathrm{SX}$ of $\mathrm{Zn}$ (II). As $\mathrm{Zn}$ (II) concentration in the original leachate was relatively low $\left(1.8 \mathrm{~g} \mathrm{~L}^{-1}, \sim 0.03 \mathrm{~mol}\right.$ $\left.\mathrm{L}^{-1}\right), 6$ vol.\% D2EHPA was sufficient to remove $\mathrm{Zn}(\mathrm{II})$ from the aqueous phase in a single stage. $\mathrm{Cu}$ (II) and $\mathrm{Al}(\mathrm{III})$ were not coextracted.
$\mathrm{Cu}$ (II) began to be extracted at $\mathrm{pH}$ around 1.3 and was fully extracted at $\mathrm{pH} \sim 2.2$. Al(III) was not practically coextracted (<0.1 wt.\%) using LIX 984 as extractant. As $\mathrm{Cu}$ (II) concentration in the original leachates was relatively high $\left(\sim 0.35 \mathrm{~mol} \mathrm{~L}^{-1}\right)$, the minimum LIX984 concentration to ensure $\mathrm{Cu}$ (II) extraction (> 99.5 wt.\%) from the leachate at $\mathrm{pH} 2.2$ was 25 vol.\% in two stages.

D2EHPA was also able to separate Al(III) from Ni(II). Acidity increased significantly after $\mathrm{SX}$ of $\mathrm{Al}(\mathrm{III})$, but this can be overcome by beginning this procedure at somewhat higher $\mathrm{pH}(\sim 4.5)$. Both elements were extracted in one stage ( $>99.5 \mathrm{wt} . \%)$ using appropriate extractant concentrations (12 vol.\% and 6 vol.\%, respectively, for $\mathrm{Al}(\mathrm{III})$ and $\mathrm{Ni}(\mathrm{II}))$. Data for both ions agree with those presented in the literature for sulfate medium. ${ }^{40,44,60-62} \mathrm{~A}$ good $\mathrm{Al}(\mathrm{III})$ extraction using D2EHPA requires previous $\mathrm{Cu}$ (II) separation in order to avoid interference. ${ }^{44,61,62}$

The general extraction reaction in the presence of D2EHPA is well established in sulfuric medium: ${ }^{63,64}$

$$
\begin{gathered}
\mathrm{X}^{2+}{ }_{\text {(aq.) }}+(\mathrm{HD})_{2 \text { (org.) }} \rightleftarrows \mathrm{X}(\mathrm{D})_{2 \text { (org.) }}+2 \mathrm{H}^{+} \text {(aq.) } \\
(\mathrm{HD}=\mathrm{D} 2 \mathrm{EHPA})
\end{gathered}
$$

A net effect of Eq. 14 is the increase of the acidity of the raffinate. Experimental data confirm that the raffinate is more acidic than the leachate: 1.6 x 1.8 ( $\mathrm{Zn}(\mathrm{II})) ; 3.7$ x 4.5 (Al(III)); 5.4 x 6.0 (Ni(II)).

The extraction order in the presence of D2EHPA in acetic and sulfuric media under increasing acidity found in this work was $\mathrm{Zn}$ (II) $-\mathrm{Al}(\mathrm{III})-\mathrm{Ni}(\mathrm{II})$. This is the same trend found in the literature in sulfate $^{40}$ and hydrofluoric ${ }^{26,47}$ media. As composition of a PCB from a cell phone varies from model to model of each brand, ${ }^{25}$ the robustness of SX should be checked, with the help of parameters such as the distribution ratio or the separation fator. ${ }^{62}$

$\mathrm{Fe}(\mathrm{III})$ was poorly extracted $(\sim 10 \mathrm{wt} . \%)$ in the presence of phosphoric acid probably due to the $\left[\mathrm{Fe}\left(\mathrm{PO}_{4}\right)_{2}\right]^{3-}$ complex..$^{27,28} \mathrm{Tin}$ was also not fully extracted in a single stage $(\sim 75 \mathrm{wt} . \%)$. On the other hand, SX of $\mathrm{Zn}$ (II) behaved in the same way as in acetic and sulfuric acid media. Fe(III) and Sn(IV) were not significantly coextracted probably because they were masked by phosphate ions. ${ }^{27,28}$

The leachates from the experiments using $\mathrm{HF}+\mathrm{H}_{2} \mathrm{O}_{2}$ presented the same behavior found for non-ground PCBs. ${ }^{26}$ D2EHPA extracted (> 99.5 wt.\%) the non-complexed ions ( $\mathrm{Zn}(\mathrm{II}), \mathrm{Cu}(\mathrm{II})$ and $\mathrm{Ni}(\mathrm{II})$ ) at $\mathrm{pH}$ far apart (1.8, 3.5 and 6) because Fe(III), Sn(IV) and $\mathrm{Al}$ (III) were masked by fluoride ions, thus not interfering in $\mathrm{Zn}$ (II) and $\mathrm{Cu}$ (II) extraction steps. ${ }^{40,43,60-64}$ As expected, $\mathrm{Fe}$ and $\mathrm{Al}$ were precipitated together as $\mathrm{Na}_{3} \mathrm{AlF}_{6}+\mathrm{Na}_{3} \mathrm{FeF}_{6}(>99.5$ wt.\%) at $\mathrm{pH} \sim 4$. XRF data show that nickel and tin contents were lower than $0.1 \mathrm{wt} . \%$. $\mathrm{Na}_{2} \mathrm{SnF}_{6}$ was recovered ( 99 wt. \%) from the solid containing $\mathrm{NaF}$ and $\mathrm{Na}_{2} \mathrm{SiF}_{6}$ after leaching it with absolute ethanol. ${ }^{26}$

Stripping of the elements from the loaded organic phases in a single stage was accomplished using sulfuric acid as follows: $0.5 \mathrm{~mol} \mathrm{~L}^{-1}(\mathrm{Ni}(\mathrm{II})) ; 1 \mathrm{~mol} \mathrm{~L}^{-1}$ ( $\left.\mathrm{Zn}(\mathrm{II}), \mathrm{Al}(\mathrm{III})\right) ; 2.5 \mathrm{~mol} \mathrm{~L}^{-1}(\mathrm{Cu}(\mathrm{II}))$; $3 \mathrm{~mol} \mathrm{~L}^{-1}(\mathrm{Fe}(\mathrm{III})) ; 6 \mathrm{~mol} \mathrm{~L}^{-1}(\mathrm{Sn}(\mathrm{IV}))$. These results agree with data presented in the literature. ${ }^{26,40-42,44,60,61}$ In other words, Fe(III) was easily scrubbed out with dilute sulfuric acid, leaving tin in the loaded organic phase. ${ }^{41,42}$

\section{Precipitation of lead sulfate (leachants: $\mathrm{CH}_{3} \mathrm{COOH}+\mathrm{H}_{2} \mathrm{O}_{2}$ and $\left.\mathrm{H}_{3} \mathrm{PO}_{4}+\mathrm{H}_{2} \mathrm{O}_{2}\right)$}

Lead was quantitatively precipitated (>99.5 wt.\%). Since it may interfere in the $\mathrm{SX}$ of $\mathrm{Cu}(\mathrm{II}),{ }^{43,45}$ lead sulfate was isolated before this step. The use of saturated sodium sulfate avoided excessive dilution of the leachate. The diffractogram of the white solid corresponds to the expected compound (Figure 5). 
Table 4. Mass percentage of elements (wt.\%) in the fine solid after sequential treatment with aqueous $\mathrm{HNO}_{3}$ and aqua regia

\begin{tabular}{|c|c|c|c|c|c|c|c|c|c|c|c|}
\hline $\begin{array}{c}\mathrm{HNO}_{3} \\
\left(\mathrm{~mol} \mathrm{~L}^{-1}\right)\end{array}$ & $\begin{array}{l}\text { Color of the } \\
\text { solid }\end{array}$ & $\mathrm{Cu}$ & $\mathrm{Ag}$ & $\mathrm{Au}$ & Pd & $\mathrm{Al}$ & $\mathrm{Fe}$ & $\mathrm{Pb}$ & Sn & $\mathrm{Si}$ & $\begin{array}{l}\text { Alkali-earth } \\
\text { metals }\end{array}$ \\
\hline \multicolumn{12}{|c|}{ A. Leachant: $\mathrm{HF}+\mathrm{H}_{2} \mathrm{O}_{2}$} \\
\hline 0 & Gray & 2.9 & $1.2 \times 10^{1}$ & 7.8 & 1.2 & 3.7 & 4.0 & $5.4 \times 10^{1}$ & 4.0 & $1.0 \times 10^{-1}$ & $1.0 \times 10^{1}$ \\
\hline 2 & Silvery & - & $5.7 \times 10^{1}$ & $3.7 \times 10^{1}$ & 5.3 & - & - & $2.0 \times 10^{-1}$ & $1.0 \times 10^{-1}$ & $4.0 \times 10^{-1}$ & $3.0 \times 10^{-1}$ \\
\hline 8 & Light brown & - & $*$ & $8.7 \times 10^{1}$ & $1.2 \times 10^{1}$ & - & - & - & - & $9.0 \times 10^{-1}$ & - \\
\hline 16 & Yellowish & - & - & $9.9 \times 10^{1}$ & - & - & - & - & - & 1.0 & - \\
\hline 4 (aqua regia) & Brownish & - & - & - & - & - & - & - & - & $1.0 \times 10^{2}$ & - \\
\hline \multicolumn{12}{|c|}{ B. Leachant: $\mathrm{H}_{2} \mathrm{SO}_{4}+\mathrm{H}_{2} \mathrm{O}_{2}$} \\
\hline 0 & Gray & 2.1 & $1.1 \times 10^{1}$ & 7.1 & 1.0 & 3.2 & 3.9 & $4.5 \times 10^{1}$ & 4.5 & $1.3 \times 10^{1}$ & 8.8 \\
\hline 2 & Silvery & - & $2.6 \times 10^{1}$ & $1.7 \times 10^{1}$ & 2.4 & - & - & - & $1.0 \times 10^{-1}$ & $3.2 \times 10^{1}$ & $2.2 \times 10^{1}$ \\
\hline 8 & Light brown & - & $*$ & $2.4 \times 10^{1}$ & 3.2 & - & - & - & - & $4.4 \times 10^{1}$ & $2.9 \times 10^{1}$ \\
\hline 16 & Light brown & - & - & $2.5 \times 10^{1}$ & - & - & - & - & - & $4.5 \times 10^{1}$ & $3.0 \times 10^{1}$ \\
\hline 4 (aqua regia) & Brown & - & - & - & - & - & - & - & - & $6.0 \times 10^{1}$ & $4.0 \times 10^{1}$ \\
\hline \multicolumn{12}{|c|}{ C. Leachant: $\mathrm{H}_{3} \mathrm{PO}_{4}+\mathrm{H}_{2} \mathrm{O}_{2}$} \\
\hline 0 & Gray & 2.0 & $2.4 \times 10^{1}$ & $1.5 \times 10^{1}$ & 2.1 & 4.2 & 1.0 & $8.0 \times 10^{-1}$ & 3.6 & $2.8 \times 10^{1}$ & $1.9 \times 10^{1}$ \\
\hline 2 & Silvery & - & $2.8 \times 10^{1}$ & $1.7 \times 10^{1}$ & 2.4 & - & - & - & - & $3.2 \times 10^{1}$ & $2.1 \times 10^{1}$ \\
\hline 8 & Light brown & - & $*$ & $2.4 \times 10^{1}$ & 3.3 & - & - & - & - & $4.4 \times 10^{1}$ & $3.0 \times 10^{1}$ \\
\hline 16 & Light brown & - & - & $2.4 \times 10^{1}$ & - & - & - & - & - & $4.5 \times 10^{1}$ & $3.1 \times 10^{1}$ \\
\hline 4 (aqua regia) & Brown & - & - & - & - & - & - & - & - & $5.9 \times 10^{1}$ & $4.1 \times 10^{1}$ \\
\hline \multicolumn{12}{|c|}{ D. Leachant: $\mathrm{CH}_{3} \mathrm{COOH}+\mathrm{H}_{2} \mathrm{O}_{2}$} \\
\hline 0 & Gray & 3.1 & $2.5 \times 10^{1}$ & $1.5 \times 10^{1}$ & 2.3 & 2.4 & 2.5 & $6.0 \times 10^{-1}$ & 2.5 & $2.7 \times 10^{1}$ & $2.0 \times 10^{1}$ \\
\hline 2 & Silvery & - & $2.8 \times 10^{1}$ & $1.7 \times 10^{1}$ & 2.6 & - & - & - & $1.0 \times 10^{-1}$ & $3.0 \times 10^{1}$ & $2.2 \times 10^{1}$ \\
\hline 8 & Light brown & - & $*$ & $2.3 \times 10^{1}$ & 3.5 & - & - & - & - & $4.2 \times 10^{1}$ & $3.1 \times 10^{1}$ \\
\hline 16 & Light brown & - & - & $2.4 \times 10^{1}$ & - & - & - & - & - & $4.4 \times 10^{1}$ & $3.2 \times 10^{1}$ \\
\hline 4 (aqua regia) & Brownish & - & - & - & - & - & - & - & - & $5.8 \times 10^{1}$ & $4.2 \times 10^{1}$ \\
\hline
\end{tabular}

* below the limit of detection.



Figure 4. Solvent extraction of metal ions as a function of $\mathrm{pH}$ of the leachate. $\mathrm{A} / \mathrm{O}=1$ vol./vol., $25^{\circ} \mathrm{C}$. Extractants: Cyanex $272(10$ vol.\%, $\mathrm{Fe}(\mathrm{III})$ and Sn(IV)); LIX 984 (25 vol.\%, Cu(II)); D2EHPA (6 vol.\%, Zn(II) and $\mathrm{Ni}(\mathrm{II}))$; D2EHPA (12 vol.\%. Al(III)). Leachants: $5 \mathrm{~mol} \mathrm{~L}^{-1} \mathrm{H}_{2} \mathrm{O}_{2}+8.5 \mathrm{~mol} \mathrm{~L}^{-1}$ $\mathrm{CH}_{3} \mathrm{COOH}$ or $9 \mathrm{~mol} \mathrm{~L}^{-1} \mathrm{H}_{2} \mathrm{SO}_{4}$

\section{The performance of new leachants for ground PCBs from cell phones}

Phosphoric acid was not a good leachant probably because the experimental conditions of this research were too mild compared to those for digestion of geological samples. ${ }^{29,30}$ Its leachate is very unstable. Only two elements were recovered ( $\mathrm{Zn}$ and $\mathrm{Pb}$ ). Fe and $\mathrm{Sn}$

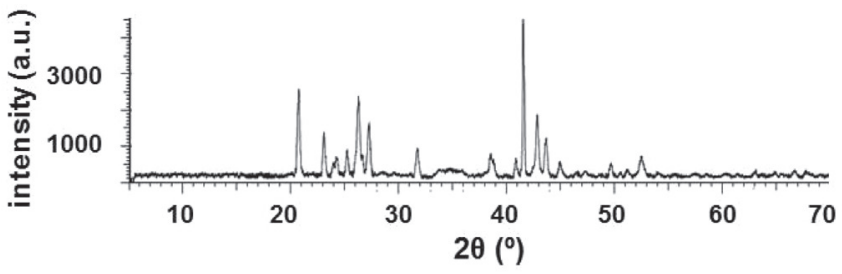

Figure 5. Diffractogram of the solid isolated after precipitation of $P b(I I)$ wirh $\mathrm{Na}_{2} \mathrm{SO}_{4 a q .}$. The peaks represent lead sulfate $\left(\mathrm{PbSO}_{4}\right)$. Leachants: $5 \mathrm{~mol} \mathrm{~L}^{-1} \mathrm{H}_{2} \mathrm{O}_{2}+8.5 \mathrm{~mol} \mathrm{~L}^{-1} \mathrm{CH}_{3} \mathrm{COOH}$ or $7.4 \mathrm{~mol} \mathrm{~L}^{-1} \mathrm{H}_{3} \mathrm{PO}_{4}$ )

were masked. The increase of $\mathrm{pH}$ above 2.5 lead to precipitation of the other leached elements. Perhaps this acid may be useful to digest PCBs under the conditions applied to geological samples for element analysis (chemical characterization) by ICP-MS, thus avoiding the use of HF.

Leaching in the presence of acetic acid was much slower than with sulfuric acid. This organic acid is much weaker than the inorganic one and the acetate anion is not a powerful ligand. Nevertheless, it avoids the use of corrosive strong inorganic acids. The processing of acetic and sulfuric leachates was very similar. The displacement of lead from a precipitate $\left(\mathrm{PbSO}_{4}\right)$ to the leachate $\left(\mathrm{Pb}\left(\mathrm{CH}_{3} \mathrm{COO}\right)_{2}\right)$ made precious metals recovery from the fine solid easier.

Hydrofluoric acid confirms its ability to leach PCBs (either ground or non-ground) in short time in the presence of hydrogen peroxide under low temperature. Processing of its leachate is easier than for 
other acids because the interfering metal ions were masked by the fluoride ion. Its main disadvantage is its toxic character.

\section{CONCLUSIONS}

Acidic leaching in the presence of hydrogen peroxide mixtures leached the base metals of the metal concentrate from ground waste PCBs under mild conditions $\left(\sim 40^{\circ} \mathrm{C}\right)$. The nature of the acid (strong/ weak) and its anion (strong/weak ligand) marked influenced the time required to accomplish full leaching (>99.5 wt.\%): $1 \mathrm{~h}(\mathrm{HF})$, $2 \mathrm{~h}\left(\mathrm{H}_{2} \mathrm{SO}_{4}\right), 4 \mathrm{~h}\left(\mathrm{H}_{3} \mathrm{PO}_{4}\right)$ and $5 \mathrm{~h}\left(\mathrm{CH}_{3} \mathrm{COOH}\right)$. Thermal effects due to decomposition of hydrogen peroxide were less pronounced for the weak acids. The leachate from $\mathrm{H}_{3} \mathrm{PO}_{4}+\mathrm{H}_{2} \mathrm{O}_{2}$ is quite unstable as many metal phosphates quickly precipitated after standing it for $1 \mathrm{~h}$ only.

The leachants can be classified into two groups: those which dissolve the ceramic/fiberglass components (HF) and those which do not react or only slightly react with them (other acids). The leachants can also be divided in those which leached lead $\left(\mathrm{H}_{3} \mathrm{PO}_{4}\right.$ and $\left.\mathrm{CH}_{3} \mathrm{COOH}\right)$ and those which precipitated it $\left(\mathrm{HF}\right.$ and $\left.\mathrm{H}_{2} \mathrm{SO}_{4}\right)$. For these reasons the insoluble matter is the highest for $\mathrm{H}_{2} \mathrm{SO}_{4}$.

Individual recovery of precious metals from the fine solid was feasible either in the presence or absence of lead, silicon and alkaliearth metals. The recovery route was simpler when silicon bearing compounds were absent. Gold could not be recovered as metal because it was mixed with fine particles of the polymer substrate and in most cases with the ceramic/fiberglass components.

Processing of the leachate by a combination of SX and precipitation steps in acidic medium is possible provided the correct choice of the extractant and the precipitant minimizes or eliminates the interference of metal ions. In any case, the correct adjustment of the acidity of the leachate is of primordial importance to perform a good separation of the metal ions. SX in acetic and sulfuric media behaved very similarly. The number of steps decreased in the order $\mathrm{CH}_{3} \mathrm{COOH}+\mathrm{H}_{2} \mathrm{O}_{2}$ (7) $\mathrm{H}_{2} \mathrm{SO}_{4}+\mathrm{H}_{2} \mathrm{O}_{2}(6)-\mathrm{HF}+\mathrm{H}_{2} \mathrm{O}_{2}$ (4). The leachates from the experiments using $\mathrm{H}_{3} \mathrm{PO}_{4}+\mathrm{H}_{2} \mathrm{O}_{2}$ could not be fully processed because a white precipitate was formed above $\mathrm{pH} 2.5$, thus preventing further separation.

Despite the unique features of some of the acidic media employed in this work, waste PCBs do represent one of the most complicated components of e-waste in terms of structure and composition. It is one of the most challenging wastes to be processed. It seems unavoidable that a multistage separation procedure is required for recovery of the profitable metals $(\mathrm{Cu}, \mathrm{Au}, \mathrm{Ag}$ and $\mathrm{Pd})$ and the relatively less economic ones.

\section{SUPPLEMENTARY MATERIAL}

Figure $1 \mathrm{~S}$ presents the general scheme for elements separation from leachates of $\mathrm{PCBs}$ of ground mobile phones after leaching with $\mathrm{H}_{2} \mathrm{SO}_{4}+\mathrm{H}_{2} \mathrm{O}_{2}, \mathrm{CH}_{3} \mathrm{COOH}+\mathrm{H}_{2} \mathrm{O}_{2}$ or $\mathrm{H}_{3} \mathrm{PO}_{4}+\mathrm{H}_{2} \mathrm{O}_{2}$ mixtures. It is available for download at http:// quimicanova.sbq.org.br in pdf format with free access.

\section{ACKNOWLEDGEMENTS}

The authors would like to thank Council of Technological and Scientific Development (CNPq) for financial support. Pedro R. Gismonti, Guido T. C. Zeba and Calvin S. M. Silva acknowledge PIBIC/CNPq-UFRJ for a fellowship.

\section{REFERENCES}

1. Rahmani, M.; Yaghamaeian, K.; Nabizadeh, R.; Yunesian, M.; Resour., Conserv. Recycl. 2014, 87, 21.
2. Estrada-Ruiz, R. H.; Flores-Campos, R.; Gámez-Altamirano, H. A.; Velarde-Sánchez, E. J.; J. Hazard. Mater. 2016, 311, 91.

3. Perkins, D. N.; Drisse, M. N. B.; Nxele, T.; Sly, P. D.; Annals of Global Health 2014, 80, 286; Parajuly, K.; Kuehr, R.; Awasthi, A. K.; Fitzpatrick, C.; Lepawsky, J.; Smith E.; Widmer, R.; Zeng, X.; Future E-waste Scenarios; United Nations University: Tokyo, 2019, p. $9-20$.

4. Gao, X.; Li, Q.; Qiu, J.; Waste Manage. 2018, 74, 427.

5. Kavousi, M.; Sattari, A.; Alamdari, E. K.; Firoz, S.; Waste Manage. 2017, 60, 636

6. Lu, Y.; Xu, Z.; Resour., Conserv. Recycl. 2016, 113, 28.

7. Kaya, M.; Waste Manage. 2016, 57, 64.

8. He, J.; Duan, C.; Waste Manage. 2017, 60, 618.

9. Zhang, L.; Xu, Z.; J. Cleaner Prod. 2016, 127, 19.

10. Xiu, F. R.; Weng, H.; Qi, Y.; Yu, G.; Zhang, Z.; Zhang, F. S.; Chen, M. A.; Waste Manage. 2017, 60, 643.

11. Rocchetti, L.; Amato, A.; Beolchini, F.; J. Cleaner Prod. 2018, $178,814$.

12. Raele, M. P.; Pretto, L. R.; Zezell, D. M.; Waste Manage. 2017, 68, 475.

13. Dutta, D.; Panda, R.; Kumari, A.; Goel, S.; Jha, M. K.; Sustainable Mater. Technol. 2018, 17, 1 .

14. Li, H.; Eksteen, J.; Oraby, E. Resour., Conserv. Recycl. 2018, 139, 122; Henrique Jr., S. S.; Moura, F. P.; Corrêa, R. S.; Afonso, J. C.; Vianna, C. A.; Mantovano, J. L.; Quim. Nova 2013, 36, 570.

15. Torres, R.; Lapidus, G. T.; Waste Manage. 2017, 60, 561.

16. Riedewald, F.; Gallagher, M. S.; Methods X 2015, 2, 100.

17. Kumar, A.; Holuszko, M.; Espinosa, D. C. R.; Resour., Conserv. Recycl. 2017, 122, 31

18. Ding, Y.; Zhang, S.; Liu, B.; Zheng, H.; Chang, C. C.; Ekberg, C.; Resour., Conserv. Recycl. 2019, 141, 284.

19. Ackil, A.; Erust, C.; Gahan, C. S.; Ozgun, M.; Sahin, M.; Tuncuk, A.; Waste Manage. 2015, 45, 258.

20. Silvas, F. P. C.; Correa, M. M. J.; Caldas, M. P. K.; Moraes, V. T.; Espinosa, D. C. R.; Waste Manage. 2015, 46, 503.

21. Mizerno, B.; Musongo, T.; Rene, E. R.; Battes, F.; Lens, P. N. L.; Process Saf. Environ. 2018, 120, 14.

22. Wang, Z.; Guo, S.; Ye, C.; Procedia Environ. Sci. 2016, 31, 917.

23. Khatri, B. R.; Sodha, A. B.; Shah, M. B.; Tipre, D. R.; Dave, S. R.; Sustainable Environ. Res. 2018, 28, 333.

24. Rizki, I. N.; Tanaka, Y.; Okibe, N.; Waste Manage. 2019, 84, 158.

25. Silva, W. C.; Corrêa, R. S.; Gismonti, P. R.; Afonso, J. C.; Silva, R. S.; Vianna, C. A.; Mantovano, J. L.; Quim. Nova 2018, 41, 1025.

26. Silva, W. C.; Corrêa, R. S.; Silva, C. S. M.; Afonso, J. C.; Silva, R. S.; Vianna, C. A.; Mantovano, J. L.; Waste Manage. 2018, 78, 781.

27. Feigl, F.; Spot Tests in Inorganic Analysis; Elsevier: Amsterdam, 1958, chap. 3.

28. Lurie, J.; Handbook of Analytical Chemistry, $3^{\text {rd }}$ ed., Mir: Moscow, 1978, chap. 3, 6, 10 .

29. Hannaker, P.; Qing-Lie, H.; Talanta 1984, 31, 1153.

30. Oliveira, A. L. B.; Afonso, J. C.; Silva, L.; Alcover Neto, A.; Carneiro, M. C.; Silva, L. I. D.; Monteiro, M. I. C.; Geostand. Geoanal. Res. 2019, 43, 689 .

31. Ribeiro, P. P. M.; Guimarães, Y. F.; Santos, I. D.; Dutra, A. J. B. In Proceedings of the XIIIth International Mineral Processing Symposium, Bodrum, Turkey, 2012.

32. Guimarães, Y. F.; Santos, I. D.; Dutra, A. J. B.; Hydrometallurgy 2014, $149,63$.

33. Cantor, S. E.; Met. Finish. 2009, 107, 58.

34. Adhapure, N. N.; Dhakephalkar, P. K.; Dhakephalkar, A. P.; Tembhurkar, V. R.; Rajgure, A. V.; Deshmukh, A. M.; Methods X 2014, 1, 181.

35. Hofmeister, C.; Maaß, S.; Flauding, T.; Mayer, T.; Mater. Chem. Phys. 2017, 185, 129.

36. Roine, A.; HSC Chemistry ver. 6.1; Outotec Research Oy, Helsinki, 2010 . 
37. Clever, H. L.; Johnston, F. J.; J. Phys. Chem. Ref. Data 1980, 9, 751.

38. Aktas, S.; Hydrometallurgy 2010, 104, 106.

39. Virolainen S., Ibana D., Paatero, E.; Hydrometallurgy 2011, 107, 56.

40. Ritcey, G. M., Ashbrook, A. W.; Principles and Applications to Process Metallurgy (Part I). Elsevier: New York, 1984, 364 p.

41. Sole, K. C.; Cole, P. C. In Ion Exchange and Solvent Extraction - A Series of Advances, vol. 15; Marcus, Y., SenGupta, A. K., eds.; Marcel Dekker: New York, 2002, chap. 3, p. 150-151; Swain, B.; Mishra, C.; Hong, H.S.; Cho, S. S.; Lee, S. K.; Green Chem. 2015, 17, 3979.

42. Deep, A.; Correia, P. F. M.; Carvalho, J. M. R.; Ind. Eng. Chem. Res. 2006, 45, 3200; Yang, J.; Ekberg, C.; Retegan, T.; Int. J. Chem. Eng. 2014, ID 186768

43. Lu, J.; Dreisinger, D.; Hydrometallurgy 2013, 137, 13.

44. Sole, K. C.; Feather, A. M.; Cole, P. C.; Hydrometallurgy 2005, 78, 52.

45. Qiu, Y.; Yang, L.; Huang, S.; Ji, Z.; Li, Y.; Chin. J. Chem. Eng. 2017, 25 , 760.

46. San Miguel, E. R.; Aguilar, J. C.; Bernal, J. P.; Ballinas, M. L.; Rodríguez, M. T. J.; de Gyves, J.; Schimmel, K.; Hydrometallurgy 1997, 47, 19.

47. Fernandes, A.; Afonso, J. C.; Dutra, A. J. B.; J. Power Sources 2012 , 220, 286.

48. Santos, I. D.; Afonso, J. C.; Dutra, A. J. B.; J. Braz. Chem. Soc. 2011, 22,875 .

49. Guilhen, S. N.; Cotrim, M. E. B.; Sakata, S. K.; Scapin, M. A.; REM: Int. Eng. J., Ouro Preto 2019, 72, 609.

50. Li, J.; Duan, H.; Yu, K.; Liu, L.; Wang, S.; Resour., Conserv. Recycl. 2010, 54,810
51. Flame retardants in printed circuit boards, final report, The US Environmental Protection Agency, National Service Center for Environmental Publications (Report 744-R-15-001), 2015.

52. Verma, H. R.; Singh, K. K.; Mankhand, T. R.; J. Cleaner Prod. 2016, 139,586

53. Birloaga, I.; Michelis, I.; Ferella, F.; Buzatu, M.; Vegliò, F.; Waste Manage. 2013, 33, 935.

54. Kinoshita, T.; Akita, S.; Kobayashi, N.; Nii, S.; Kawaizumi, F.; Takahashi, K.; Hydrometallurgy 2003, 69, 73.

55. Oh, C. J.; Lee, S. O.; Yang, H. S.; Ha, T. J.; Kim, M. J.; J. Air Waste Manage. 2003, 53, 897.

56. Vats, M. C.; Singh, S. K.; Waste Manage. 2015, 45, 280.

57. Mohapatra, M.; Anand, S.; Mishra, B. K.; Giles, D. E.; Singh, P.; J. Environ. Manage. 2009, 91, 67.

58. Charles, R. G.; Douglas, P.; Hallin, I. L.; Matthews, I.; Liversage, G.; Waste Manage. 2017, 60, 505.

59. Portella, K. F.; Rattmann, K. R.; Souza, G. P.; Garcia, C. M.; Cantão, M. P.; J. Mater. Sci. 2000, 35, 3263.

60. Virolaien, S.; Ibana, N.; Paatero, E.; Hydrometallurgy 2011, 107, 56.

61. Uang, J.; Retegan, T.; Ekberg, C.; Hydrometallurgy 2013, 137, 68.

62. Cui, H.; Anderson, C. G.; J. Adv. Chem. Eng. 2016, 6, 142; Correa, M. M. J.; Silvas, F. P. C.; Aliprandini, P.; Moraes, V. T.; Dreisinger, D.; Espinosa, D. C. R.; Braz. J. Chem. Eng. 2018, 35, 919.

63. Fuerstenau, M. C., Wang, G.; Hydrometallurgy 1997, 46, 229.

64. Gouvea, L. R.; Morais, C. A.; Miner. Eng. 2010, 23, 492. 